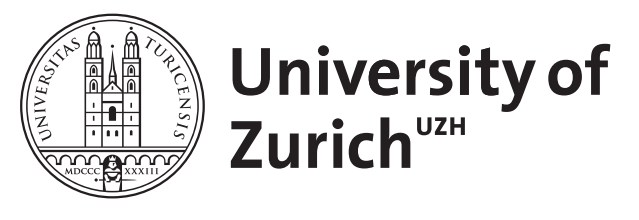

\title{
Blood doping and its detection
}

\author{
Jelkmann, W ; Lundby, C
}

\begin{abstract}
Hemoglobin mass is a key factor for maximal exercise capacity. Some athletes apply prohibited techniques and substances with intent to increase hemoglobin mass and physical performance, and this is often difficult to prove directly. Autologous red blood cell transfusion cannot be traced on reinfusion, and also recombinant erythropoietic proteins are detectable only within a certain timeframe. Novel erythropoietic substances, such as mimetics of erythropoietin (Epo) and activators of the Epo gene, may soon enter the sports scene. In addition, Epo gene transfer maneuvers are imaginable. Effective since December 2009, the World Anti-Doping Agency has therefore implemented "Athlete Biologic Passport Operating Guidelines," which are based on the monitoring of several parameters for mature red blood cells and reticulocytes. Blood doping may be assumed, when these parameters change in a nonphysiologic way. Hematologists should be familiar with blood doping practices as they may play an important role in evaluating blood profiles of athletes with respect to manipulations, as contrasted with the established diagnosis of clinical disorders and genetic variations.
\end{abstract}

DOI: https://doi.org/10.1182/blood-2011-02-303271

Posted at the Zurich Open Repository and Archive, University of Zurich ZORA URL: https://doi.org/10.5167/uzh-50843

Journal Article

Published Version

Originally published at:

Jelkmann, W; Lundby, C (2011). Blood doping and its detection. Blood, 118(9):2395-2404.

DOI: https://doi.org/10.1182/blood-2011-02-303271 


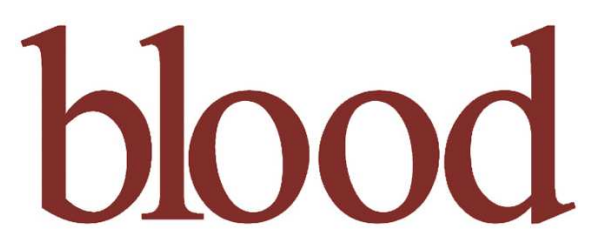

2011 118: 2395-2404

Prepublished online June 7, 2011; doi:10.1182/blood-2011-02-303271

\section{Blood doping and its detection}

Wolfgang Jelkmann and Carsten Lundby

Updated information and services can be found at:

http://bloodjournal.hematologylibrary.org/content/118/9/2395.full.html

Articles on similar topics can be found in the following Blood collections

Red Cells, Iron, and Erythropoiesis (271 articles)

Review Articles (346 articles)

Information about reproducing this article in parts or in its entirety may be found online at:

http://bloodjournal.hematologylibrary.org/site/misc/rights.xhtml\#repub_requests

Information about ordering reprints may be found online at:

http://bloodjournal.hematologylibrary.org/site/misc/rights.xhtml\#reprints

Information about subscriptions and ASH membership may be found online at:

http://bloodjournal.hematologylibrary.org/site/subscriptions/index.xhtml

Blood (print ISSN 0006-4971, online ISSN 1528-0020), is published weekly by the American Society of Hematology, 2021 L St, NW, Suite 900,

Washington DC 20036.

Copyright 2011 by The American Society of Hematology; all rights reserved.

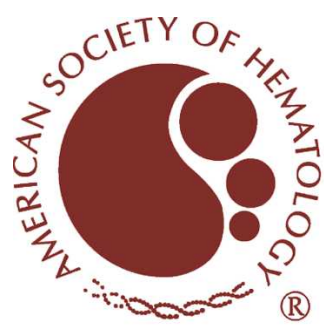




\title{
Blood doping and its detection
}

\author{
Wolfgang Jelkmann ${ }^{1}$ and Carsten Lundby ${ }^{2}$ \\ ${ }^{1}$ Institute of Physiology, University of Lübeck, Lübeck, Germany; and ${ }^{2}$ Center for Integrative Human Physiology, University of Zürich, Zürich, Switzerland
}

\begin{abstract}
Hemoglobin mass is a key factor for maximal exercise capacity. Some athletes apply prohibited techniques and substances with intent to increase hemoglobin mass and physical performance, and this is often difficult to prove directly. Autologous red blood cell transfusion cannot be traced on reinfusion, and also recombinant erythropoietic proteins are detectable only within a certain timeframe. Novel erythropoietic substances, such as mi-
\end{abstract}

metics of erythropoietin (Epo) and activators of the Epo gene, may soon enter the sports scene. In addition, Epo gene transfer maneuvers are imaginable. Effective since December 2009, the World AntiDoping Agency has therefore implemented "Athlete Biologic Passport Operating Guidelines," which are based on the monitoring of several parameters for mature red blood cells and reticulocytes. Blood doping may be assumed, when these parameters change in a nonphysiologic way. Hematologists should be familiar with blood doping practices as they may play an important role in evaluating blood profiles of athletes with respect to manipulations, as contrasted with the established diagnosis of clinical disorders and genetic variations. (Blood. 2011;118(9): 2395-2404)

\section{Introduction}

The World Anti-Doping Agency (WADA) defines blood doping as "the misuse of certain techniques and/or substances to increase one's red blood cell mass, which allows the body to transport more $\mathrm{O}_{2}$ to muscles and therefore increase stamina and performance."1 Prohibited procedures include the use of synthetic $\mathrm{O}_{2}$ carriers, the transfusion of red blood cells (RBCs), the infusion of hemoglobin $(\mathrm{Hb})$, and the artificial stimulation of erythropoiesis. This review focuses on erythropoietic substances and RBC parameters that are affected by blood doping and provided the basis for WADA's "Athlete Biologic Passport Operating Guidelines." Synthetic $\mathrm{O}_{2}$ carriers, such as $\mathrm{Hb}$-based $\mathrm{O}_{2}$ carriers or perfluorocarbons, are not considered here. The topic is timely. Experts having knowledge in the fields of clinical hematology, laboratory medicine/ hematology, and physiology/hematology may become involved in the evaluation of athletes' blood profiles. The experts must be able to analyze and certify whether a blood value abnormality is the result of doping or the result of an acute disorder, respectively, a genetic variation. ${ }^{3}$

Several paragraphs of the "2011 Prohibited List" of the WADA are relevant as regards blood doping. ${ }^{1}$ First, under "Prohibited Substances" ("S2. Peptide hormones, growth factors and related substances"), several erythropoiesis-stimulating agents (ESAs) are itemized: erythropoietin (Epo), darbepoetin-alfa, hypoxia-inducible factor (HIF) stabilizers, methoxy polyethylene glycol-epoetin $\beta$ (CERA), and peginesatide (Hematide; Affymax). Second, under "Prohibited Methods" forbidden blood products are specified ("M1. Enhancement of oxygen transfer"). Furthermore, intravenous infusions (unless clinically legitimated) and the sequential withdrawal, manipulation and reinfusion of whole blood are prohibited ("M2. Chemical and physical manipulation"). Finally, genetic interventions with the potential to enhance sport performance are defined ("M3. Gene doping"), including "the transfer of nucleic acids or nucleic acid sequences, the use of normal or genetically modified cells, and the use of agents that directly or indirectly affect functions known to influence performance by altering gene expression."

\section{$\mathrm{Hb}$ mass and physical performance}

In aerobic sport disciplines, such as long-distance running, cycling, or cross-country skiing, the main factors determining performance are a high delivery of $\mathrm{O}_{2}$ to the exercising skeletal muscles and its use (Figure 1). The rate of maximal $\mathrm{O}_{2}$ uptake $\left(\mathrm{O}_{2 \text { max }}\right)$ is dependent on a high cardiac output $(\mathrm{Q})$ and a wide difference for arterialvenous $\mathrm{O}_{2}\left(\mathrm{a}-\mathrm{vO}_{2}\right)$, that is, the Fick equation: ${ }^{\circ} \mathrm{O}_{2 \max }=\mathrm{Q}_{\max } \times$ $\mathrm{a}-\mathrm{vO}_{2 \text { max }}$. Because (1) $\mathrm{Q}_{\max }$ is difficult (if not impossible) to manipulate to higher values during competitions, (2) the distribution of Q during maximal exercise to the working skeletal muscles is close to $80 \%$, and (3) arterial $\mathrm{O}_{2}$ extraction is already in the range of approximately $90 \%$ at maximal exercise, the only variable that remains open for manipulations in regards to increasing exercise performance is the arterial $\mathrm{O}_{2}$ content. Accordingly, in a given person, changes in $\mathrm{Hb}$ concentration $([\mathrm{Hb}])$ by either $\mathrm{RBC}$ transfusion or hemodilution will increase or decrease $\mathrm{O}_{2 \max }$, respectively. ${ }^{4}$ On the group basis, however, $[\mathrm{Hb}]$ is not predictive of $\mathrm{O}_{2 \text { max }}$, whereas the total mass of $\mathrm{Hb}\left(\mathrm{Hb}_{\text {mass }}\right)$ correlates very well with $\mathrm{O}_{2}$ max. ${ }^{5}$ Indeed, a somewhat reduced [ $\left.\mathrm{Hb}\right]$ is sometimes, but not always, observed among athletes, whereas $\mathrm{Hb}_{\text {mass }}$ is usually increased compared with normal healthy persons (Figure 2).

The first experiments with blood transfusions and exercise were performed by Pace et al, ${ }^{6}$ who demonstrated that the transfusion of $450 \mathrm{~mL}$ of whole blood on 4 consecutive days decreases submaximal exercise heart rate (in hypoxia) for several weeks, and hence predicted that exercise performance would be increased. Accordingly, it was calculated in a recent review that a change of $1 \mathrm{~g}$ in $\mathrm{Hb}_{\text {mass }}$ will produce a change in ${ }^{\circ} \mathrm{O}_{2 \max }$ of $4 \mathrm{~mL} \mathrm{~min}^{-1},{ }^{7}$ whereas the effects on submaximal exercise performance are probably variable according to competition distance. It should also be noted here that 


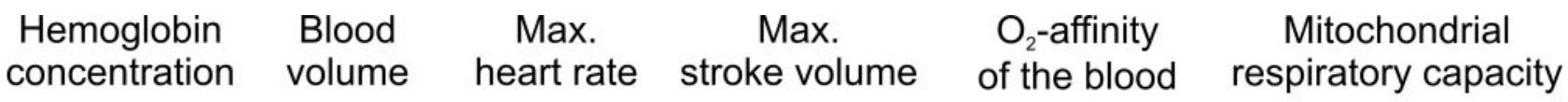

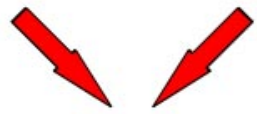

Hemoglobin mass

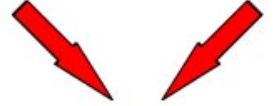

Max. cardiac output

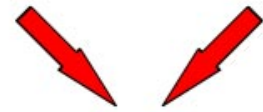

Max. $\mathrm{O}_{2}$-extraction
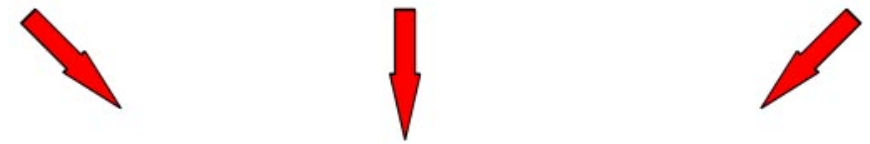

\section{Aerobic capacity (Max. $\mathrm{O}_{2}$ uptake)}

Figure 1. Parameters determining the aerobic capacity. The aerobic capacity, as measured as the maximal $\mathrm{O}_{2}$ uptake ( $\mathrm{O}_{2}$ max $)$, depends primarily on the person's total $\mathrm{Hb}$ mass, the maximal cardiac output, and the maximal $\mathrm{O}_{2}$ extraction in the heart and the skeletal muscles. The total $\mathrm{Hb}_{\text {mass }}$ results from the blood hemoglobin concentration and the blood volume.

volume loading (ie, plasma volume expansion) in itself does not lead to an improved exercise performance in elite athletes, ${ }^{8}$ again highlighting the role of $\mathrm{Hb}_{\text {mass. }}$ If, however, a plasma volume expander is administrated simultaneously with increments in $\mathrm{Hb}_{\text {mass }}$, then performance will probably increase more than when just augmenting the total red cell volume. ${ }^{9}$
Individual values

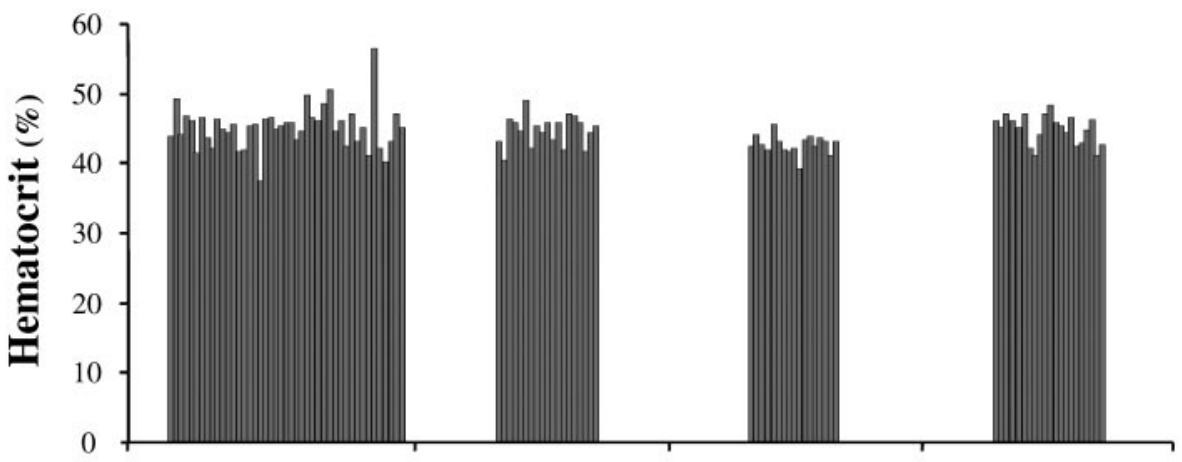

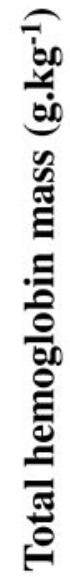

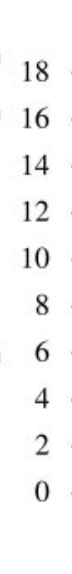

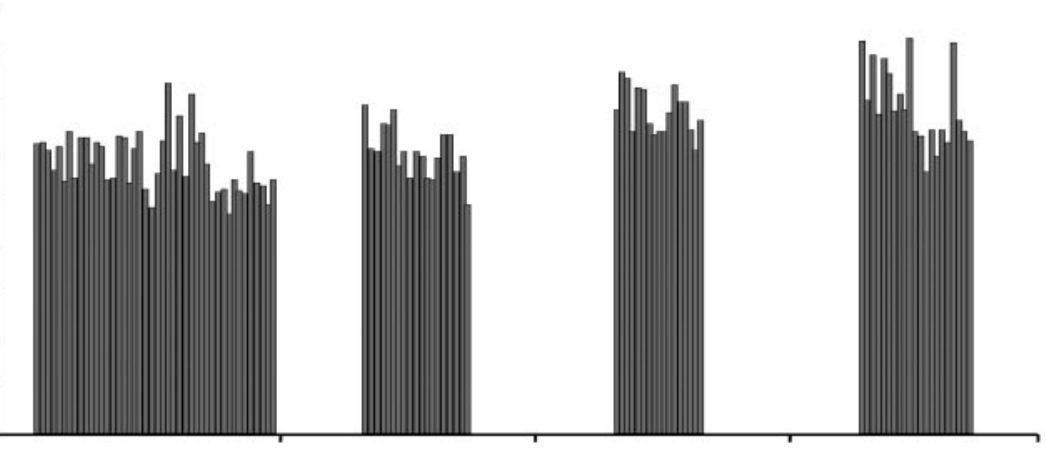

Moderately-trained Trained runners Highly trained Elite cross-country individuals $(\square)$

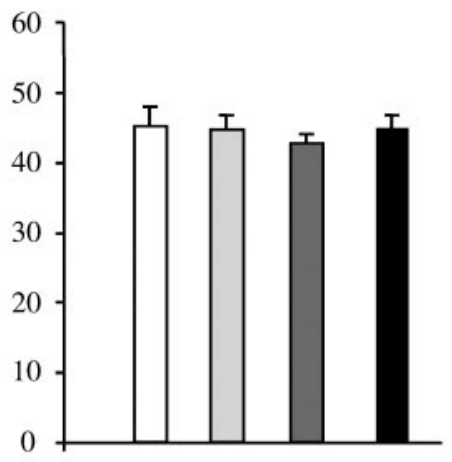

( $\square$ ) $n=44$

$n=19$ cyclists ( $\square$ ) skiers (ם) $\mathrm{n}=17$

$\mathrm{n}=\mathbf{2 1}$

Figure 2. Hematocrit (\%) and total $\mathrm{Hb}_{\text {mass }}(\mathbf{g} / \mathbf{k g})$. Measures were made in moderately trained young males (Danish, commuting to work/school on bicycle and engaged in easy aerobic training 1-3 times per week); in trained runners (French, all finishers of the "Ultra Trail du Mont Blanc," $166 \mathrm{~km}$ of mountain trail running with $9500 \mathrm{~m}$ of altitude gain); in national level cyclists (Danish, American, Canadian); and in national team cross-country skiers (German, Swedish, and French), including several Olympic and World Championship medalists. The figure illustrates that elite athletes may have similar hematocrit values compared with healthy persons, but that $\mathrm{Hb} \mathrm{b}_{\text {mass }}$ is increased. ${ }^{\star} P<.001$ versus moderately trained persons. The data were collected by C.L., Paul Robach, and Bengt Saltin between 2005 and 2011 in a joint effort. 


\section{The influence of Epo on exercise performance}

The performance enhancing (ergogenic) effect of recombinant human Epo (rhEpo) in aerobic sports was investigated shortly after the medicine became available. ${ }^{10,11}$ It soon became clear that subcutaneous administration of rhEpo at doses of 60 to $350 \mathrm{U} / \mathrm{kg}$ body weight and week for 4 to 6 weeks increases $\mathrm{O} 2_{\max }$ and the time to exhaustion substantially. ${ }^{10,12,13}$ More recent studies in which rhEpo was applied to healthy volunteers in lower dosages demonstrated that ${ }^{\circ} \mathrm{O}_{2 \max }$ is increased by $6 \%-12 \%$ when the hematocrit (Hct) is increased to approximately 0.50 but also demonstrated that time to exhaustion (in the laboratory) at a given level of $\mathrm{O}_{2 \max }$ is increased by up to $50 \% .{ }^{14} \mathrm{~A}$ challenge for antidoping work is that when rhEpo administration is discontinued in healthy volunteers, $\mathrm{O}_{2 \text { max }}$ remains elevated for at least 3 weeks. Effects of rhEpo in normal humans have been reviewed recently. ${ }^{15}$ Although Epo is reported to activate several nonhematologic factors (ie, in addition to stimulating erythropoiesis), which are usually also associated with improvements in aerobic performance, the primary mechanism by which Epo increases exercise performance in humans is through augmented erythropoiesis. ${ }^{16-18}$ ESAs are particularly effective in combination with iron supplementation. ${ }^{19}$ The administration of iron results in increased ferritin levels in athletes. ${ }^{20}$ Ferritin levels more than $1000 \mu \mathrm{g} / \mathrm{L}$ have been observed. ${ }^{21}$

There are as yet no reports on physical performance in healthy humans with increased circulating Epo and $\mathrm{Hb}_{\text {mass }}$ because of the administration of compounds stimulating the expression of the endogenous Epo gene or after Epo gene transfer.

\section{Direct detection of blood doping}

Blood and urine samples can be taken in-competition and out-ofcompetition. With respect to reservations that a venipuncture is a medical intervention and may violate the tenets of certain religious or cultural groups, the WADA has stated that there is no basis for such provisos. ${ }^{1}$

\section{RBC transfusion}

A test for detection of allogeneic blood transfusion doping was implemented in 2004. The test uses blood group antisera to identify mixed RBC populations in blood samples by flow cytometry. Nelson et $\mathrm{al}^{22}$ applied antisera against 12 blood group antigens and demonstrated that the presence of allogeneic cells can be assessed in the blood of subjects who had previously received at least one unit of allogeneic blood. Giraud et $\mathrm{al}^{23}$ carried out a single-blind and single-site study to validate the flow cytometry method as a forensic quality standard analysis and to allow objective interpretation of real cases. No false-positive results were obtained in an analysis of 140 blood samples containing different percentages (0\%-5\%) of a minor RBC population, indicating a $100 \%$ specificity of the method. Most samples containing a $1.5 \%$ minor RBC population were unambiguously detected, yielding a $78 \%$ sensitivity. The method proved to fulfill the ISO-17025 accreditation and validation requirements. ${ }^{23}$ Athletes making use of allogeneic blood transfusion are thus very likely to be caught if tested.

Autologous RBC manipulations can at present only be detected via indirect measures, which represents a major problem in antidoping efforts. The $\mathrm{CO}$ rebreathing technique for detecting nonphysiologic increases in $\mathrm{Hb}_{\text {mass }}$ is still investigational, ${ }^{24,25}$ and besides practical difficulties related to this method, its potential inclusion in the blood passport may be problematic, ${ }^{26}$ because the margin of variation when assessing $\mathrm{Hb}_{\text {mass }}$ (biologic and measurement errors) would still allow athletes to manipulate with blood volumes that would increase exercise performance considerably. ${ }^{27}$ Finally, it should also be considered that, from an athlete's viewpoint, it may not be desirable to breathe $\mathrm{CO}$ shortly before a competition as this may limit exercise performance.

\section{Peptidic ESAs}

Currently available rhEpo preparations (epoetins) are produced in Epo complementary DNA (cDNA) transfected Chinese hamster ovary $(\mathrm{CHO})$ or baby hamster kidney $(\mathrm{BHK})$ cell cultures. The only therapeutic rhEpo engineered in human cells (epoetin $\delta$ ) is off market since the beginning of 2009 (Table 1). Because the patents of the originator epoetins have died, biosimilar products have been approved in many parts of the world.$^{28}$ Furthermore, various copied $\mathrm{CHO}$ cell-derived rhEpos are available in countries without a regulated market. ${ }^{29}$

Endogenous Epo and the epoetins have an invariant sequence of 165 amino acids, but they differ in glycosylation. Compared with the epoetins, endogenous Epo isoforms are more acidic ${ }^{30-32}$ and smaller in size. ${ }^{33}$ Epo can be separated by isoelectric focusing (IEF) or electrophoresis of urine samples. After IEF, a double-blotting procedure is performed. The mutein darbepoetin-alfa migrates more in the acidic range than Epo on IEF. ${ }^{30,31}$ The WADA has established criteria to achieve harmonization in the performance of the test for epoetin and darbepoetin in urine. ${ }^{34}$ Actually, when urine samples from rhEpo-treated subjects were submitted to 2 WADAaccredited laboratories, the results were not fully consistent, ${ }^{35}$ which, as claimed by the laboratories, was apparently the result of methodologic differences. A recent detection problem has arisen with the addition of proteases by athletes to their urinary samples, which destroys the erythropoietic proteins. ${ }^{36,37}$ The adulteration of urine with proteases is a prohibited method, ${ }^{1}$ and techniques have been developed for the detection of their misuse. ${ }^{38}$

Another difficulty relates to the fact that once $[\mathrm{Hb}]$ has been raised in athletes by the administration of recombinant ESAs, only microdoses or less frequent injections of the drugs are needed to maintain $[\mathrm{Hb}]$ at the high level. ${ }^{39}$ In this situation, the window of detection of rhEpo in urine is only $12-18$ hours, ${ }^{40}$ compared with about 3 days on regular dosing $(50 \mathrm{U} / \mathrm{kg}$ body weight 3 times a week). ${ }^{41}$ Thus, although the detection of rhEpo in urine is effective if the injection frequency is high, this is certainly not the case when the injection rate is reduced to weekly injections. ${ }^{35}$ Because darbepoetin-alfa has a 3- to 4-fold longer half-life (24-26 hours) ${ }^{42}$ than the epoetins (6-8 hours), the window of detection of darbepoetin-alfa is prolonged to approximately 7 days. ${ }^{43,44}$ CERA has an even longer half-life of approximately 6 days. ${ }^{45}$ IEF of CERA yields bands in the less acidic area compared with native Epo. ${ }^{46} \mathrm{IEF}$ for investigation of doping with CERA has also been applied to blood samples. ${ }^{47}$ In addition, CERA can be detected by ELISA.

Table 1 gives an overview of recent Epo-like molecules and derivatives that have entered preclinical or clinical trials and are potential candidates for misuse in sports. Of particular interest are recombinant fusion proteins of Epo with the Fc region of human IgG because one of these was shown to stimulate erythropoiesis, when administered as an aerosol in a phase 1 trial. $^{48}$ 
Table 1. Erythropoiesis-stimulating compounds and techniques prohibited in sports

\begin{tabular}{|c|c|c|c|}
\hline Compound/technique & Manufacturer & Development/approval status & $\begin{array}{l}\text { Pharmacologic } \\
\text { references }\end{array}$ \\
\hline \multicolumn{4}{|l|}{ Recombinant products } \\
\hline $\begin{array}{l}\text { Originator epoetins } \\
(\alpha, \beta, \theta) \text {, biosimilar } \\
\text { epoetins }(\alpha, \kappa, \zeta)\end{array}$ & $\begin{array}{l}\text { Recombinant DNA technology Epo-transfected } \\
\mathrm{CHO} \text { cells }\end{array}$ & $\begin{array}{l}\text { Country- and product-specific marketing } \\
\text { authorization in North America, Australia, Asia, } \\
\text { European Union }\end{array}$ & 28(R), 29(R), 46(R), 58(R) \\
\hline Epoetin- $\alpha$ copies & Epo-transfected $\mathrm{CHO}$ cells & $\begin{array}{l}\text { Marketed in Asia, Central and South America, } \\
\text { Africa }\end{array}$ & 29(R), 46(R), 125(R) \\
\hline Epoetin- $\omega$ & Epo-transfected BHK cells & Marketed in South Africa & $46(\mathrm{R})$ \\
\hline Epoetin- $\delta$ & $\begin{array}{l}\text { Cytomegalovirus promoter-transfected HT-1080 } \\
\text { cells }\end{array}$ & No longer available (marketing stopped in 2009) & 29(R), 46(R), 125(R) \\
\hline Methoxy-PEG-epoetin- $\beta$ & Epo-transfected $\mathrm{CHO}$ cells, pegylated & Marketed in European Union and Asia & 29(R), 45(R), 46(R) \\
\hline Darbepoetin-alfa & $\begin{array}{l}\text { Mutated Epo-transfected } \mathrm{CHO} \text { cells, } \\
\text { hyperglycosylated }\end{array}$ & $\begin{array}{l}\text { Marketed in European Union, North America, } \\
\text { Australia, Asia }\end{array}$ & $42,43,29(R), 46(R)$ \\
\hline Epo fusion proteins & Recombinant DNA technology & Clinical trials & $48,125(R)$ \\
\hline \multicolumn{4}{|l|}{$\begin{array}{l}\text { Еро-Еро, Еpo-Fc, } \\
\text { Еро- } \beta \text { HCG }\end{array}$} \\
\hline Peptidic Epo mimetics & Chemical synthesis & Clinical trials & 29(R), 46(R) \\
\hline Pegisenatide & PEG coupled & & $49-51$ \\
\hline CNTO 528, CNTO 530 & Fused to recombinant immunoglobulin & & 52,53 \\
\hline Epo gene activators & Chemical synthesis & & 125(R) \\
\hline HIF stabilizers & & & 55(R), 65(R), 66(R) \\
\hline Cobalt & & Unapproved administration & $59,61,60(\mathrm{R})$ \\
\hline $\begin{array}{l}\alpha \text {-Ketoglutarate } \\
\text { competitors }\end{array}$ & & Clinical trials & 67 \\
\hline GATA inactivators & & Preclinical trials & $68-70$ \\
\hline \multirow[t]{2}{*}{ Epo gene transfer } & In vivo gene transfer & Preclinical trials & $71-75$ \\
\hline & In vitro gene transfer & Clinical trials & 79 \\
\hline
\end{tabular}

Modified from Jelkmann. ${ }^{125}$

(R) indicates review.

Epo mimetic peptides (EMPs) are synthetic cyclic peptides of about 20 amino acids. A potent pegylated EMP dimer (INN: peginesatide; Hematide) proved to stimulate erythropoiesis in experimental animals ${ }^{49}$ and in healthy male volunteers. ${ }^{50}$ Peginesatide is currently in phase 3 trials for the treatment of patients with chronic renal failure (CKD). Peginesatide can be detected by enzyme-linked immunoassay. ${ }^{49}$ In a clinical trial on 14 patients with CKD, who had pure red cell aplasia because of anti-Epo antibodies and were treated with peginesatide for 28 months, neutralizing antibodies against the drug occurred in one of the patients. ${ }^{51}$ This should further discourage athletes to use the medicine as a doping means.

In an alternative approach, EMPs have been constructed onto human IgG1-based scaffolds by recombinant DNA technology. The seminal compound, CNTO 528 (Centocor), produced a reticulocytosis and increased $[\mathrm{Hb}]$ on intravenous administration in a phase 1 study in healthy men. ${ }^{52}$ The follow-on product CNTO 530, a dimeric EMP fused to a human IgG4 Fc scaffold, has been shown to expand the pool of erythroid progenitors in vitro and in vivo. ${ }^{53}$

\section{Drugs activating the endogenous Epo gene}

The Epo enhancer is under the control of HIFs, heterodimeric proteins composed of the subunits $\alpha$ and $\beta$. HIF-2 is the main factor inducing Epo expression. ${ }^{54}$ The $C$-terminus of HIF- $\alpha$ is composed of proline residues that are hydroxylated in the presence of $\mathrm{O}_{2}$. Prolyl hydroxylated HIF- $\alpha$ binds the von Hippel-Lindau tumor suppressor protein in complex with an E3-ligase and undergoes immediate proteasomal degradation. The transcriptional activity of the HIFs is suppressed by $\mathrm{O}_{2}$-dependent hydroxylation of an asparagine residue. The HIF- $\alpha$ hydroxylases contain $\mathrm{Fe}^{2+}$ and are inactivated by $\mathrm{Fe}^{2+}$ removal. ${ }^{55}$ However, iron chelators are not suited for stimulation of erythropoiesis in the long-term because iron is required for heme synthesis. HIF-dependent Epo expression is augmented by divalent transition metals, such as cobalt or nickel. It has been known that cobalt increases erythropoiesis in experimental animals. ${ }^{56}$ Cobalt binds to HIF- $\alpha$, thereby preventing the docking of von Hippel-Lindau tumor suppressor protein. ${ }^{57}$ Cobalt is a very potent inducer of Epo transcription. Indeed, the international Epo unit (IU) was originally defined as the dose eliciting the same erythropoiesis stimulating response in rats as $5 \mu \mathrm{mol}$ of cobaltous chloride.58 The treatment of anemic CKD patients with cobalt (commonly administered as enteric-coated tablets, $30-150 \mathrm{mg}$ daily $)^{59,60}$ is no longer performed because of its toxicity. ${ }^{61}$ However, cobalt may be misused by athletes as a proper means to enhance Epo levels and $\mathrm{Hb}_{\text {mass }}{ }^{62}$ Cobalt is very potent, inexpensive, and not comprehended in the WADA's "Prohibited List." Furthermore, the HIF- $\alpha$ hydroxylases require $\alpha$-ketoglutarate for their catalytic action. ${ }^{55} \alpha$-Ketoglutarate competitors ("HIF stabilizers") are orally active compounds that stimulate Epo production and erythropoiesis. ${ }^{63,64} \mathrm{~A}$ number of chemically different HIF stabilizers has been identified. ${ }^{65,66} \mathrm{~A}$ phase 1 clinical trial investigating effects of the $\alpha$-ketoglutarate competitor FG-2216 (FibroGen) in CKD patients has been reported. ${ }^{67}$ However, HIF stabilizers induce the expression of more than 200 genes apart from Epo, ${ }^{65,66}$ which may result in serious unwanted effects in athletes. On the other hand, it is probable that some of the HIF-activated genes encode proteins that may increase physical performance (eg, glycolytic enzymes, glucose transporters, and angiogenic peptides). 


\section{Epo production}

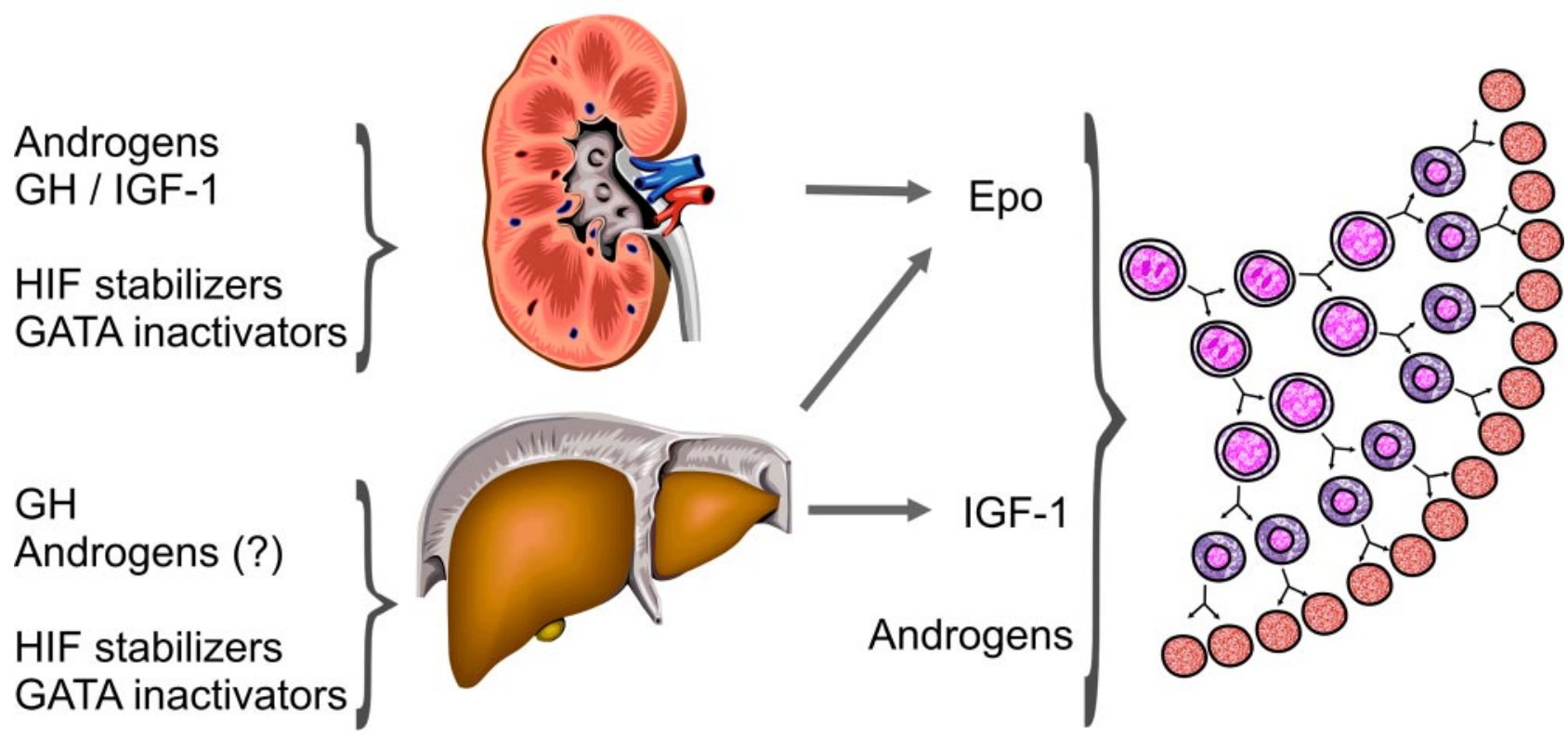

Figure 3. Control of erythropoiesis and starting points for blood doping. The hormone Epo, which derives from kidneys and liver, stimulates the survival, proliferation, and differentiation of the erythrocytic progenitors in hemopoietic tissues. The enhanced release of reticulocytes leads to an increase in the blood hemoglobin concentration and, thus, the $\mathrm{O}_{2}$ capacity of the blood and the total $\mathrm{Hb}$ mass. Epo gene expression in the kidneys and the liver is controlled at the transcriptional level. Because the Epo enhancer is activated by the HIF, chemicals stabilizing HIF, such as cobalt and $\alpha$-ketoglutarate competitors, increase Epo expression. GATA inactivators release the Epo promoter from the inhibition by GATA-2. Androgenic steroids and GH, respectively IGF-1, augment the production of Epo and the proliferation of erythrocytic progenitors.

GATA inhibitors are nonpeptidic organic compounds that prevent GATA-2 from suppressing the Epo promoter ${ }^{68,69}$ Initially, the GATA inhibitor K-7174, a diazepane derivative, was used. Subsequent reports have indicated that the follow-on product $\mathrm{K}-11706$ exerts even stronger erythropoietic effects in vitro and in experimental animals. ${ }^{69,70} \mathrm{~K}-11706$ was already shown to increase physical performance in mice. ${ }^{70}$

\section{Epo gene transfer}

A viral gene delivery vector carrying the human Epo gene under the control of an $\mathrm{O}_{2}$-dependent hypoxia response element (Repoxygen; Oxford BioMedica) was earlier developed that might have been misused for Epo gene doping. Reportedly, however, the technique never proceeded beyond animal experiments. ${ }^{71}$ In addition, in vivo Epo gene transfer could probably be detected if applied by athletes, as an IEF study revealed unusual Epo glycosylation forms on allogeneic Epo transfer into skeletal muscle of cynomolgus macaques via adeno-associated virus. ${ }^{72}$ In the initial studies of adeno-associated virus-mediated allogeneic Epo cDNA transfer to macaques, severe anemia developed in many animals after a few months, which was probably the result of an immune reaction. ${ }^{73,74}$ However, in using a rapamycin dimerizer-regulated gene expression system, Rivera et $\mathrm{al}^{75}$ achieved controlled, long-term production (up to 6 years) of Epo in rhesus monkeys, with no apparent immune response. Regarding the possibility of Epo gene doping in humans, strategies are under development to specifically amplify intron-less DNA sequences and PCR protocols allowing the detection of small amounts of transgenic DNA in blood. ${ }^{76-78}$ The tests take into consideration that transgenes are usually derived from the cDNA for the gene to be transferred and cDNA does not contain introns.
An autologous ex vivo approach was chosen in the first human Epo gene therapy trial on patients with CKD. ${ }^{79}$ An individual dermal core sample was transfected with Epo cDNA inserted into a vector containing the cytomegalovirus promoter and the simian virus-40 polyA site. When the dermal cores were reimplanted under the abdominal skin, serum Epo levels peaked in most cases on day 3 and then decreased, reaching baseline levels, probably because of immunologic rejection of the transplants. The transient Epo increase produced a reticulocytosis but was not sufficient to raise $[\mathrm{Hb}]$ levels. ${ }^{79}$

In conclusion, Epo gene transfer is possible but medically little explored with respect to efficacy, safety, and immunogenicity. It seems less likely that any of the techniques has entered the sports scene.

\section{Other erythropoietic hormones}

Several hormones may stimulate the renal and/or hepatic production of Epo, including prostanoids, thyroid hormone, angiotensin II, growth hormone $(\mathrm{GH})$, and testosterone. The latter are of particular interest regards blood doping (Figure 3).

A study in anemic CKD patients has shown that plasma Epo levels increase 6 hours after the start of GH infusion, with peak values reached after 96 hours. ${ }^{80}$ The fact that the rise in plasma Epo occurred earlier than the rise in insulin-like growth factor-1 (IGF-1) indicates that $\mathrm{GH}$ directly stimulates Epo production. IGF-1 was earlier shown to promote the growth of erythrocytic progenitors. ${ }^{81}$ The concentration of circulating IGF-1 correlates with Hct in CKD patients. ${ }^{82}$ Synthetic GH secretagogues (ghrelin mimetics), recombinant human GH, and recombinant human IGF-1 are available for therapeutic purposes. 
Anabolic-androgenic steroids also increase both the production of Epo and the proliferation of erythrocytic progenitors in the bone marrow, as reviewed elsewhere. ${ }^{83}$

\section{WADA's "Biologic Passport"}

Traditional antidoping analyses are based on the detection of a substance in biologic fluids ("Adverse analytical finding"). This approach has major limitations in regard to blood doping. As outlined in the previous section, autologous blood cannot be detected, there is a plethora of ESAs, the detection window is limited, and there is urine manipulation. Some sports federations earlier introduced upper $[\mathrm{Hb}]$ and $\mathrm{Hct}$ limits to escape from this dilemma. Athletes tested above the limits were declared unfit for competition ("No-start rule"). However, $[\mathrm{Hb}]$ and Hct are influenced by external factors, such as body posture, exercise, or residence at altitude. In addition, "clean" athletes can have naturally high $[\mathrm{Hb}]$ and Hct values. A large retrospective study on male blood donors in Denmark revealed that $3.9 \%$ of nonathletes and $10.4 \%$ of elite rowers had Hct values more than 0.51 (ie, above the recommended limits for athletic competition). ${ }^{84}$ In addition, Cazzola ${ }^{21}$ warned that the adoption of upper [Hb] and Hct limits may paradoxically generate more blood doping because, by ESA misuse, $[\mathrm{Hb}]$ and Hct can be manipulated with the aim of approaching the target values without exceeding it.

Hematologic parameters depend on ethnicity, age, and gender. Even [Hb] values differ. ${ }^{85}$ Hence, it has been suggested to use longitudinal blood profiles together with heterogeneous factors, such as ethnicity and age, to develop models with improved sensitivity to detect blood doping. ${ }^{86-88}$ Some blood parameters, such as the concentration of Epo and reticulocytes (Ret), increase on administration of ESAs (ON-score), whereas they decrease after $\mathrm{RBC}$ transfusion or after the cessation of ESA administration (OFF-score). ${ }^{86,89-94}$ The "Abnormal Blood Profile Score" (not presently used for the assessment of abnormal blood profiles based on the passport data) regards additional red cell parameters, including the mean corpuscular $\mathrm{Hb}$ concentration (MCHC), mean corpuscular volume (MCV), mean corpuscular $\mathrm{Hb}$ mass $(\mathrm{MCH})$, Ret counts, serum Epo, and soluble transferrin receptor (sTfR). ${ }^{95}$ Algorithms have been used that are sensitive during one of the two phases, with ON-score being sensitive during ESA treatment and OFF-score during the cessation phase. Details of the calculation of these scores are described elsewhere. ${ }^{96}$

Having become effective in December 2009, the "Athlete Biologic Passport Operating Guidelines"2 equip Anti-Doping Organizations with a framework in which to pursue antidoping rule violations in accordance with Article 2.2. of the World Anti-Doping (WAD) Code ("Use or Attempted Use by an Athlete of a Prohibited Substance or a Prohibited Method"). The guidelines include mandatory requirements for collection, transportation, analysis of blood samples, and results management. The following markers are considered in the Athlete Biologic Passport hematologic module: $\mathrm{Hct}, \mathrm{Hb}, \mathrm{RBC}$ count, reticulocyte percentage, reticulocyte number, $\mathrm{MCV}, \mathrm{MCH}, \mathrm{MCHC}$, and OFF-hr score (Index of stimulation derived from the formula: $([\mathrm{Hb}](\mathrm{g} / \mathrm{L})-60 \times \sqrt{ }$ (reticulocyte percentage); normal range, 85-95). In addition, parameters of interest can be the mean Ret cell volume (MCVr), Ret $\mathrm{Hb}$ concentration $(\mathrm{MCHCr})$ and Ret $\mathrm{Hb}$ content $(\mathrm{MCHr})$, as measured by flow cytometry as in clinical routine. ${ }^{97}$ The results reported to the WADA are processed by an "Adaptive Model" that identifies abnormal blood parameter changes related to the athlete's individual profile. In particular, $[\mathrm{Hb}]$ or OFF-hr score abnormalities with a $99.9 \%$ probability or more will be reviewed by experts. ${ }^{2}$

\section{RBC parameters associated with autologous retransfusion}

The failure to obtain direct proof for autologous blood transfusion has prompted the search for indirect evidence. In a preliminary antidoping context, Damsgaard et $\mathrm{al}^{98}$ reported changes in hematologic parameters after blood withdrawal and reinfusion. Ten healthy men were subjected to withdrawal of $20 \%$ of their blood volume (and hence much more than common doping practice), which was replaced by $1.3 \mathrm{~L}$ of hydroxyl-ethyl starch. Circulating Epo increased 4-fold within a day, declining exponentially thereafter. Reticulocyte number increased 2.4-fold after 7 days, remaining elevated for another 7 days. [Hb] remained reduced on average by $15 \%$ for 2 weeks. sTfR increased by $60 \%$ by day 14 and remained elevated until 3 days after reinfusion of $0.8 \mathrm{~L}$ of packed RBCs, which was performed one month later. Thereby, $[\mathrm{Hb}]$ increased acutely by $8 \%$ returning to the initial baseline value after 7 days. Epo concentrations remained unchanged, whereas reticulocyte numbers were reduced by approximately $30 \%$ from days 7 to 21 . Only one of the men in this study showed $[\mathrm{Hb}]$ values higher than $170 \mathrm{~g} / \mathrm{L},{ }^{98}$ thereby exceeding the upper limit offset by some sport federations for male athletes. None of the men demonstrated positive OFF-scores according to the model of Gore et al, ${ }^{86}$ which renders this model less effective in detecting blood transfusion doping. ${ }^{98}$ The loss of $\mathrm{Hb}_{\text {mass }}$ of approximately $75 \mathrm{~g}$ (measured by CO rebreathing) after donation of $550 \mathrm{~mL}$ blood has been shown to be recovered after a mean of 36 days. ${ }^{99}$ After the retransfusion of one $\mathrm{RBC}$ unit $\mathrm{Hb}_{\text {mass }}$ acutely increased by $51 \mathrm{~g}$, showing a continuous decrease from week 2 until week 8, albeit $\mathrm{Hb}_{\text {mass }}$ was still elevated compared with pre-reinfusion values. ${ }^{100}$ Based on the results of a retrospective longitudinal blinded study, the same group of investigators has reported that the use of an adaptive model incorporating hematologic measures $([\mathrm{Hb}]$, reticulocyte percentage, OFF-score) allows for detection of autologous blood transfusion. ${ }^{101}$ In a comparative study of 3 blood passport approaches and 4 blood markers, Mørkeberg et al ${ }^{102}$ retransfused 29 subjects with either 1 or 3 units of autologous blood. Hbmr (derived from the formula $\left[4.51 \times \ln \left(\mathrm{Hb}_{\text {mass }}\right)-V\right.$ reticulocyte percentage]; currently not part of antidoping testing) demonstrated superior sensitivity in detecting blood transfusion. ${ }^{102}$ The same authors have reported that the determination of the ratio between the mass of $\mathrm{Hb}$ in the mature erythrocyte population and in the reticulocyte fraction $\left(\mathrm{RBC}_{\mathrm{Hb}} / \mathrm{Ret}_{\mathrm{Hb}}\right.$ ratio) is the best indicator of autologous blood doping. ${ }^{103}$

\section{RBC parameters associated with ESA doping}

There are no major differences in basal [Hb], RBC count, Hct, and MCHC values in elite athletes compared with healthy nonathletes. ${ }^{104}$ When blood samples obtained from 413 female and 739 male elite athletes from 12 countries were screened for hematologic abnormalities, $1 \%$ of the females and $1.4 \%$ of the males had hemoglobinopathies. ${ }^{105}$ Furthermore, $2.4 \%$ of the females and $0.7 \%$ of the males were iron-deficient with or without anemia. ${ }^{105}$ Accelerated erythropoiesis resulting from the use of 
rhEpo may lead to the production of iron-deficient reticulocytes (reduced $\mathrm{MCHr}$ ), even when iron stores are normal. ${ }^{106}$ An increase in hypochromic red cells has been seen on rhEpo therapy despite the use of parenteral or oral iron. ${ }^{107}$ Reticulocyte number was not affected by intravenous iron administration in healthy humans subjected to a bolus injection of rhEpo (300 U/kg intravenously). ${ }^{19}$ However, $\mathrm{MCHr}$ and Ret $[\mathrm{Hb}]$ were increased in the intravenous iron/rhEpo group compared with the group receiving rhEpo alone. Thus, intravenous iron increases the hemopoietic response to rhEpo in normal subjects, and this therapy is probably practiced by cheating athletes. Note that parenteral iron alone did not produce a change in $\mathrm{Hb}_{\text {mass }}$, [Hb], or specific $\mathrm{RBC}$ parameters in young female athletes, despite their low baseline [Hb] $(128 \mathrm{~g} / \mathrm{L})$ and serum ferritin $(35 \mu \mathrm{g} / \mathrm{L})$ levels. ${ }^{108}$

There is fair stability of reticulocyte number in top-level athletes, ${ }^{109}$ although decreases were observed in some athletes during competition periods. ${ }^{110}$ High and middle fluorescence (immature) Ret with a high RNA content (IRF) are relatively frequent in athletes because of continuous bone marrow stimulation linked to hemolysis, which is typical of sports activities. ${ }^{110}$ Bolus rhEpo injections (150 U or $300 \mathrm{U} / \mathrm{kg}$ body weight) further increase the IRF. ${ }^{111}$ The increase in immature Ret starts 36 hours after a single dose of rhEpo, reaching a peak after 3-4 days and normalizing within 7 days. ${ }^{111}$ A pharmacodynamic model calculation has revealed that rhEpo transiently increases the life span of circulating Ret from the baseline value of 1.7 days to 3.4 days. ${ }^{112}$ Thus, the treatment with rhEpo appears to increase Ret values 2-fold: by increased Ret release from the bone marrow and by prolonged maturation time of circulating Ret.

Audran et $\mathrm{al}^{12}$ studied the time course of reticulocyte number after repeated subcutaneous injections of rhEpo $(50 \mathrm{U} / \mathrm{kg}$ body weight every day) in athletes. Reticulocyte numbers were increased from day 10 to 24 and remained elevated for 7 days after cessation of rhEpo therapy. Reticulocyte numbers were significantly lower than the baseline values 14 and 25 days after the last rhEpo injection. During treatment up to 14 days after the last rhEpo injection, sTfR and the sTfR/serum protein ratio were elevated above baseline. ${ }^{12}$ Russell et al ${ }^{113}$ administered first high $(50 \mathrm{U} / \mathrm{kg}$ body weight 3 times a week for 3 weeks) and then low doses of rhEpo (20 U/kg 3 times a week for 5 weeks), with oral or parenteral iron supplementation. Reticulocyte percentage approximately doubled by day 8 of the high-dose rhEpo treatment, but during the low-dose phase was not different from baseline values or from those of the placebo group, irrespective of the route of iron administration. During the washout phase, reticulocyte percentage fell to about half of the baseline values in the rhEpo-treated subjects. In a similar study, after frequent weekly injections for 14 days and a concomitant doubling in reticulocyte percentage, reticulocyte percentage returned to basal levels despite weekly rhEpo injections and continuously high $[\mathrm{Hb}]$, suggesting a decreased sensitivity to prolonged rhEpo treatment. ${ }^{39}$ In accordance, low-dose treatment with rhEpo ( $\sim 15 \mathrm{U} / \mathrm{kg} 3$ times a week) did not increase reticulocyte percentage above normal in subjects with elevated $[\mathrm{Hb}]$ because of previous high doses of rhEpo. ${ }^{40}$ However, there are no published data to exclude the possibility that low-dose rhEpo may stimulate erythropoiesis sufficiently to mask the decrease in reticulocyte percentage after RBC transfusion. Parisotto et $\mathrm{al}^{90}$ subjected recreational athletes to rhEpo treatment ( $50 \mathrm{U} / \mathrm{kg} 3$ times a week for 4 weeks), either supplemented with oral or intramuscular iron. The authors analyzed combinations of Hct, Ret-Hct, serum Epo, sTfR, and percentage macrocytes by logistic regression. The ON-model identified 94\%-100\% of rhEpo group members during the final 2 weeks of the treatment phase. One false positive was recorded from a possible 189. The OFF-model, incorporating Ret-Hct, Epo, and Hct, identified $67 \%-72 \%$ of recent uses with no false positive, when applied during the washout phase and the period of 12-21 days after the last rhEpo injection. ${ }^{90}$

After a single administration of high-dose Epo $(200 \mathrm{U} / \mathrm{kg}) \mathrm{Hb}$ and Hct did not increase despite an increase in reticulocyte number. ${ }^{114}$ The subcutaneous administration of rhEpo $(\sim 200 \mathrm{U} / \mathrm{kg}$ per week) and oral iron ( $270 \mathrm{mg} /$ day) for 30 days produced an increase in Hct from 42.7 to 50.8 , as well as in sTfR (from 3.1$6.3 \mathrm{mg} / \mathrm{L}$ ) and the ratio between sTfR and ferritin (from 3.211.8). ${ }^{13}$ Casoni et al ${ }^{115}$ administered rhEpo subcutaneously at doses of $30 \mathrm{U} / \mathrm{kg}$ body weight every other day for 30-45 days to 20 subjects practicing sports at an amateur level. rhEpo treatment was accompanied by twice weekly administration of parenteral iron (62 mg intravenously) and oral vitamins. The rhEpo-treated subjects had higher values for RBC concentrations, [Hb], Hct, $\mathrm{MCV}$, reticulocyte percentage, macrocyte (volume $>120 \mathrm{fL}$ ), and hypochromic macrocyte counts $(\mathrm{MCH}<28 \mathrm{pg}$ ) compared with a control population of 240 elite athletes from various sport disciplines. Breymann et $\mathrm{al}^{116}$ studied the effect of rhEpo in healthy adults when given at different time intervals. Fifteen volunteers were randomly selected to receive twice rhEpo $(300 \mathrm{U} / \mathrm{kg}$ ) and parenteral iron $(200 \mathrm{mg})$, either within a 24 - or 72 -hour interval. Controls received parenteral iron only. When second rhEpo administration was after 72 hours, volunteers showed significantly higher reticulocyte number in the high percentage of young RNA-rich Ret (HFR ratio) over several days compared with those who received rhEpo within a 24-hour interval. Both rhEpo-treated groups showed an increase in MCVr. MCHCr was inversely correlated with the increasing cell size with a nadir on day $8 .{ }^{116}$

However, apart from blood transfusion or ESA administration, other (legal) stimuli can affect some of the parameters included in the blood passport. One such example is altitude exposure. Residence at altitude may be associated with an Epo-induced increase in $[\mathrm{Hb}]$, and it is important to discriminate between the effects of hypoxia and rhEpo misuse. Parisotto et al ${ }^{89}$ have reported that reticulocyte number, Ret $\mathrm{Hb}$ mass (Ret-Hb), and the ratio between $\mathrm{RBC} \mathrm{Hb}$ mass ( $\mathrm{RBC}-\mathrm{Hb}$ ) and Ret-Hb in nonathletic subjects treated with rhEpo (1200 U/kg body weight over a 9- to 10-day period) are more significantly increased than the ones in elite cyclists training at altitude $(1780$ and $2690 \mathrm{~m})$. Ashenden et al $^{117}$ retrospectively evaluated hematologic data from 19 elite cyclists who lived and trained $2690 \mathrm{~m}$ above sea level for approximately 1 month, from 6 elite canyon runners who lived $2100 \mathrm{~m}$ above sea level but descended to compete at sea level and from 39 well-trained subjects who resided at sea level but slept at a simulated altitude of 2650 to $3000 \mathrm{~m}$ for 20 to 23 days of either consecutive or intermitted nightly exposure. On ascend to a terrestrial altitude, ON- and OFF-model scores increased immediately, mainly because of an increase in [Hb]. Scores had not returned fully to baseline 3 weeks after return to sea level because of the persistence of the raised $[\mathrm{Hb}]$ for the $\mathrm{ON}$ - and OFF-scores and the fall in reticulocyte percentage for OFF-scores. ${ }^{117}$ Abellan et $\mathrm{al}^{118}$ have reported that short-term hypoxia exposure (simulated altitude of 4000-5500 $\mathrm{m}$ in a hypobaric chamber) for 3 hours/day, 5 days a week, for 5 weeks does not cause an increase in reticulocyte percentage, $[\mathrm{Hb}]$, and sTfR. Interestingly, the hypoxia exposure was associated with a shift of urinary Epo isoforms toward the basic area on IEF. However, these shifts could not be confused with the pattern on rhEpo misuse. ${ }^{118}$ It should be kept in mind, however, that none of the aforementioned altitude studies was able to show 
increases in $\mathrm{Hb}_{\text {mass }}$ or performance and that they did not comply with the minimum recommendations of at least 400 hours of altitude/hypoxia exposure needed to increase performance. Hence, if the passport approach was to be tested in combination with an altitude setting actually leading to performance gains, it seems very likely that also many of the parameters included in the blood passport will change substantially, which needs to be accounted for during the evaluation process.

\section{Discussion}

The WAD Code states that a positive analytical result (ie, proof of the presence of a prohibited substance) will always establish liability for a doping offense. ${ }^{119}$ If a medication an athlete is required to take to treat an illness or condition falls under the "Prohibited List," a "Therapeutic Use Exemption" may give the athlete the authorization to take the needed medicine. ${ }^{1}$

Regarding blood doping, the traditional analyses based on the detection of a substance in biologic fluids have major limitations. Presently, only the misuse of allogeneic blood can be directly detected, whereas retransfused autologous blood is not detectable. There is a plethora of novel ESAs that are difficult to uncover. To overcome the detection problems, the "Athletes Biologic Passport" has been developed, which is based on the monitoring of selected RBC parameters. Blood doping may be suspected, when these parameters change in a nonphysiologic way. There are several subjects for debate concerning the passport approach, including (1) the measuring devices, (2) the processing of the analytical data and the assessment of abnormal parameters to be the result of doping, (3) the applicability in sports practice, and (4) the impact on research.

There are methodologic problems because of the lack of clear standardization and harmonization in antidoping testing. The longitudinal evaluation of several hematologic variables needs high comparability among various analytical technologies used by the different accredited laboratories. Although some parameters (ie, [Hb] and Hct) are comparable when measured on different instrumentations, others (ie, percentage of macrocytes or Ret parameters) are peculiar. ${ }^{26}$ This bears the risk of false-positive results in athletes. On the other hand, when 400 blood samples obtained from 24 subjects receiving rhEpo injections were screened by the passport parameters, $42 \%$ of the subjects were not identified as rhEpo doped. ${ }^{120}$
The statistical approach for evaluating the passport data are focused on the biologic variation of hematologic values. Critical experts in the analysis of laboratory data have argued that antidoping tests are based on fraud statistics. ${ }^{121}$ Sottas et al ${ }^{122}$ have stated that antidoping is a forensic science, not a medical one. In forensics, the traditional assumptions of "absolute certainty" and "discernible uniqueness" are abandoned in favor of an empirical and probabilistic approach.

Current antidoping actions in competitive sports are advocated for reasons of fair play and concern for the athlete's health. Most of the efforts concern elite athletes with much less impact on amateur sports and the general public. ${ }^{123}$ Indeed, antidoping rules adopted pursuant to the WAD Code normally apply only to internationaland national-caliber athletes. The monitoring of RBC parameters according to the biologic passport is not performed in recreationallevel or masters competitors who are not current or potential national-caliber competitors. Thus, the procedure is of little use in leisure sports.

In the end, a comment should be passed with respect to plans of the WADA to extend the passport by working on an endocrine module that includes androgenic steroid profiling ("Endocrine module") as well as on other possible modules. To propose that an adverse analytical finding is because of doping, knowledge of the action of the suspected substance must first be gained in healthy athletes. For example, the effects of androgenic steroids and recombinant human growth hormone needed to be investigated in healthy young subjects. ${ }^{124}$ In the authors' mind, this is an ethical dilemma.

\section{Acknowledgments}

W.J. has evaluated research grant applications to the World Anti-Doping Agency and the Federal German Institute of Sports Science. C.L. has on numerous occasions received funding from the Danish Anti Doping Agency for his research.

\section{Authorship}

Contribution: W.J. and C.L. wrote the manuscript.

Conflict-of-interest disclosure: The authors declare no competing financial interests.

Correspondence: Wolfgang Jelkmann, Institute of Physiology, University of Luebeck, D-23562 Luebeck, Germany; e-mail: jelkmann@physio.uni-luebeck.de.

\section{References}

1. World Anti-Doping Agency. http://www. wada-ama.org/en. Accessed February 2011.

2. World Anti-Doping Agency. Athlete Biological Passport Operating Guidelines. http://www. wada-ama.org/en/Science-Medicine/AthleteBiological-Passport/Operating-Guidelines. Accessed February 2011

3. Mercer KW, Densmore JJ. Hematologic disorders in the athlete. Clin Sports Med. 2005;24(3):599621.

4. Calbet JA, Lundby C, Koskolou M, Boushel R. Importance of hemoglobin concentration to exercise: acute manipulations. Respir Physiol Neurobiol. 2006;151(2):132-140.

5. Martino M, Gledhill N, Jamnik V. High $\mathrm{VO}_{2} \max$ with no history of training is primarily due to high blood volume. Med Sci Sports Exerc. 2002;34(6): 966-971.
6. Pace N, Consolazio WV, Lozner EL. The effect of transfusions of red blood cells on the hypoxia tolerance of normal men. Science. 1945;102(2658): 589-591.

7. Schmidt W, Prommer N. Impact of alterations in total hemoglobin mass on $\mathrm{VO}_{2}$ max. Exerc Sport Sci Rev. 2010;38(2):68-75.

8. Warburton DE, Gledhill N, Quinney HA. Blood volume, aerobic power, and endurance performance: potential ergogenic effect of volume loading. Clin J Sport Med. 2000;10(1):59-66.

9. Sawka MN, Convertino VA, Eichner ER, Schnieder SM, Young AJ. Blood volume: importance and adaptations to exercise training, environmental stresses, and trauma/sickness. Med Sci Sports Exerc. 2000;32(2):332-348.

10. Ekblom B, Berglund B. Effect of erythropoietin administration on maximal aerobic power in man Scand J Med Sci Sports. 1991;1(2):88-93.

11. Berglund B, Ekblom B. Effect of recombinant human erythropoietin treatment on blood pressure and some haematological parameters in healthy men. J Intern Med. 1991;229(2):125-130.

12. Audran M, Gareau R, Matecki S, et al. Effects of erythropoietin administration in training athletes and possible indirect detection in doping control. Med Sci Sports Exerc. 1999;31(5):639-645.

13. Birkeland KI, Stray-Gundersen J, Hemmersbach P, Hallen J, Haug E, Bahr R. Effect of rhEPO administration on serum levels of STfR and cycling performance. Med Sci Sports Exerc. 2000;32(7):12381243.

14. Thomsen JJ, Rentsch RL, Robach P, et al. Prolonged administration of recombinant human 
erythropoietin increases submaximal performance more than maximal aerobic capacity. Eur J Appl Physiol. 2007;101(4):481-486.

15. Lundby C, Olsen NV. Effects of recombinant human erythropoietin in normal humans. J Physiol. 2011;589(6):1265-1271.

16. Lundby C, Robach P, Boushel R, et al. Does recombinant human Epo increase exercise capacity by means other than augmenting oxygen transport? J App/ Physiol. 2008;105(2):581-587.

17. Lundby C, Hellsten $Y$, Jensen MB, Munch AS, Pilegaard $\mathrm{H}$. Erythropoietin receptor in human skeletal muscle and the effects of acute and longterm injections with recombinant human erythropoietin on the skeletal muscle. J Appl Physiol. 2008;104(4):1154-1160.

18. Rasmussen P, Foged EM, Krogh-Madsen R, et al. Effects of erythropoietin administration on cerebral metabolism and exercise capacity in men. J Appl Physiol. 2010;109(2):476-483.

19. Major A, Mathez-Loic F, Rohling R, Gautschi K, Brugnara $C$. The effect of intravenous iron on the reticulocyte response to recombinant human erythropoietin. Br J Haematol. 1997;98(2):292294.

20. Zotter H, Robinson N, Zorzoli M, Schattenberg L, Saugy M, Mangin P. Abnormally high serum ferritin levels among professional road cyclists. $\mathrm{Br}$ $J$ Sports Med. 2004;38(6):704-708.

21. Cazzola M. A global strategy for prevention and detection of blood doping with erythropoietin and related drugs. Haematologica. 2000;85(6):561563.

22. Nelson M, Popp H, Sharpe K, Ashenden M. Proof of homologous blood transfusion through quantification of blood group antigens. Haematologica. 2003;88(11):1284-1295.

23. Giraud S, Robinson N, Mangin P, Saugy M. Scientific and forensic standards for homologous blood transfusion anti-doping analyses. Forensic Sci Int. 2008;179(1):23-33.

24. Gore CJ, Bourdon PC, Woolford SM, Ostler LM, Eastwood A, Scroop GC. Time and sample site dependency of the optimized co-rebreathing method. Med Sci Sports Exerc. 2006;38(6):11871193.

25. Prommer N, Sottas PE, Schoch C, Schumacher YO, Schmidt W. Total hemoglobin mass: a new parameter to detect blood doping? Med Sci Sports Exerc. 2008;40(12):2112-2118.

26. Banfi G, Lombardi G, Colombini A, Lippi G. A world apart: inaccuracies of laboratory methodologies in antidoping testing. Clin Chim Acta. 2010;411(15):1003-1008.

27. Lundby C, Robach P. Assessment of total haemoglobin mass: can it detect erythropoietin-induced blood manipulations? Eur J Appl Physiol. 2010; 108(1):197-200

28. Jelkmann W. Biosimilar epoetins and other "follow-on" biologics: update on the European experiences. Am J Hematol. 2010;85(10):771780.

29. Macdougall IC, Ashenden M. Current and upcoming erythropoiesis-stimulating agents, iron products, and other novel anemia medications. Adv Chronic Kidney Dis. 2009;16(2):117-130.

30. Lasne F, Martin L, Crepin N, de Ceaurriz J. Detection of isoelectric profiles of erythropoietin in urine: differentiation of natural and administered recombinant hormones. Anal Biochem. 2002; 311(2):119-126.

31. Catlin DH, Breidbach A, Elliott S, Glaspy J. Comparison of the isoelectric focusing patterns of darbepoetin-alfa, recombinant human erythropoietin, and endogenous erythropoietin from human urine. Clin Chem. 2002;48(11):2057-2059

32. Pascual JA, Belalcazar V, de Bolos C, Gutierrez R, Llop E, Segura J. Recombinant erythropoietin and analogues: a challenge for doping control. Ther Drug Monit. 2004;26(2):175-179.
33. Kohler M, Ayotte C, Desharnais P, et al. Discrimination of recombinant and endogenous urinary erythropoietin by calculating relative mobility values from SDS gels. Int J Sports Med. 2008;29(1): 1-6.

34. WADA. Harmonization of the method for the identification of Epoetin alfa and beta (EPO) and Darbepoetin-alfa (NESP) by IEF-double blotting and chemiluminescent detection. http:// www.wada-ama.org/rtecontent/document/ td2009eop_en.pdf. Accessed February 2011.

35. Lundby C, Achman-Andersen NJ, Thomsen JJ, Norgaard AM, Robach P. Testing for recombinant human erythropoietin in urine: problems associated with current anti doping testing. J Appl Physiol. 2008;105(2):417-419.

36. Lamon S, Robinson N, Sottas PE, et al. Possible origins of undetectable EPO in urine samples. Clin Chim Acta. 2007;385(1):61-66.

37. Thevis M, Maurer J, Kohler M, Geyer H, Schänzer W. Proteases in doping control analysis. Int J Sports Med. 2007;28(7):545-549.

38. Thomas A, Kohler M, Walpurgis K, Schänzer W, Thevis M. Proteolysis and autolysis of proteases and the detection of degradation products in doping control. Drug Test Anal. 2009;1(2):81-86.

39. Lundby C, Thomsen JJ, Boushel R, et al. Erythropoietin treatment elevates haemoglobin concentration by increasing red cell volume and depress ing plasma volume. J Physiol. 2007;578(1):309314.

40. Ashenden M, Varlet-Marie E, Lasne F, Audran M. The effects of microdose recombinant human erythropoietin regimens in athletes. Haematologica. 2006;91(8):1143-1144.

41. Breidbach A, Catlin DH, Green GA, Tregub I, Truong $\mathrm{H}$, Gorzek J. Detection of recombinant human erythropoietin in urine by isoelectric focusing. Clin Chem. 2003;49(6):901-907.

42. Elliott S, Lorenzini T, Asher S, et al. Enhancement of therapeutic protein in vivo activities through glycoengineering. Nat Biotechnol. 2003;21(4): 414-421.

43. Lamon S, Robinson N, Mangin P, Saugy M. Detection window of Darbepoetin-alpha following one single subcutaneous injection. Clin Chim Acta. 2007;379(1):145-149.

44. Morkeberg J, Lundby C, Nissen-Lie G, Nielsen TK, Hemmersbach P, Damsgaard R. Detection of darbepoetin-alfa misuse in urine and blood: a preliminary investigation. Med Sci Sports Exerc. 2007;39(10):1742-1747.

45. Macdougall IC. CERA (Continuous Erythropoietin Receptor Activator): a new erythropoiesisstimulating agent for the treatment of anemia Curr Hematol Rep. 2005;4(6):436-440.

46. Reichel C, Gmeiner G. Erythropoietin and analogs. Handb Exp Pharmacol. 2010;195:251-294.

47. Lasne F, Martin L, Martin J, de Ceaurriz J. Isoelectric profiles of human erythropoietin are different in serum and urine. Int J Biol Macromol. 2007;41(3):354-357.

48. Dumont JA, Bitonti AJ, Clark D, Evans S, Pickford M, Newman SP. Delivery of an erythropoietin-Fc fusion protein by inhalation in humans through an immunoglobulin transport pathway. J Aerosol Med. 2005;18(3):294-303.

49. Fan Q, Leuther KK, Holmes CP, et al. Preclinical evaluation of Hematide, a novel erythropoiesis stimulating agent, for the treatment of anemia. Exp Hematol. 2006;34(10):1303-1311.

50. Stead RB, Lambert J, Wessels D, et al. Evaluation of the safety and pharmacodynamics of Hematide, a novel erythropoietic agent, in a phase 1, double-blind, placebo-controlled, doseescalation study in healthy volunteers. Blood. 2006;108(6):1830-1834.

51. Macdougall IC, Rossert J, Casadevall N, et al. A peptide-based erythropoietin-receptor agonist for pure red-cell aplasia. N Engl J Med. 2009; 361(19):1848-1855.
52. Bouman-Thio E, Franson K, Miller B, et al. A Phase I, single and fractionated, ascending-dose study evaluating the safety, pharmacokinetics, pharmacodynamics, and immunogenicity of an erythropoietin mimetic antibody fusion protein (CNTO 528) in healthy male subjects. J Clin Pharmacol. 2008;48(10):1197-1207.

53. Sathyanarayana $P$, Houde E, Marshall D, et al. CNTO 530 functions as a potent EPO mimetic via unique sustained effects on bone marrow proerythroblast pools. Blood. 2009;113(20):49554962.

54. Haase VH. Hypoxic regulation of erythropoiesis and iron metabolism. Am J Physiol Renal Physiol. 2010;299(1):F1-F13.

55. Bruegge K, Jelkmann W, Metzen E. Hydroxylation of hypoxia-inducible transcription factors and chemical compounds targeting the HIF-alpha hydroxylases. Curr Med Chem. 2007;14(17): 1853-1862.

56. Goldwasser E, Jacobson LO, Fried W, Plzak LF. Studies on erythropoiesis: V. The effect of cobalt on the production of erythropoietin. Blood. 1958; 13(1):55-60.

57. Yuan Y, Hilliard G, Ferguson T, Millhorn DE. Cobalt inhibits the interaction between hypoxiainducible factor-alpha and von Hippel-Lindau protein by direct binding to hypoxia-inducible factoralpha. J Biol Chem. 2003;278(18):15911-15916.

58. Jelkmann W. Efficacy of recombinant erythropoietins: is there unity of international units? Nephrol Dial Transplant. 2009;24(5):1366-1368.

59. Gardner FH. The use of cobaltous chloride in the anemia associated with chronic renal disease. $J$ Lab Clin Med. 1953;41(1):56-64.

60. Taylor A, Marks V. Cobalt: a review. J Hum Nutr. 1978;32(3):165-177

61. Curtis JR, Goode GC, Herrington J, Urdaneta LE. Possible cobalt toxicity in maintenance hemodialysis patients after treatment with cobaltous chloride: a study of blood and tissue cobalt concentrations in normal subjects and patients with terminal and renal failure. Clin Nephrol. 1976; 5(2):61-65.

62. Lippi G, Franchini M, Guidi GC. Blood doping by cobalt: should we measure cobalt in athletes? J Occup Med Toxicol. 2006;1:18.

63. Safran M, Kim WY, O'Connell F, et al. Mouse model for noninvasive imaging of HIF prolyl hydroxylase activity: assessment of an oral agent that stimulates erythropoietin production. Proc Natl Acad Sci U S A. 2006;103(1):105-110.

64. Hsieh MM, Linde NS, Wynter A, et al. HIF prolyl hydroxylase inhibition results in endogenous erythropoietin induction, erythrocytosis, and modest fetal hemoglobin expression in rhesus macaques. Blood. 2007;110(6):2140-2147.

65. FraisI P, Aragones J, Carmeliet P. Inhibition of oxygen sensors as a therapeutic strategy for ischaemic and inflammatory disease. Nat Rev Drug Discov. 2009;8(2):139-152.

66. Nagel S, Talbot NP, Mecinovic J, Smith TG, Buchan AM, Schofield CJ. Therapeutic manipulation of the HIF hydroxylases. Antioxid Redox Signal. 2010;12(4):481-501.

67. Bernhardt WM, Wiesener MS, Scigalla P, et al. Inhibition of prolyl hydroxylases increases erythropoietin production in ESRD. J Am Soc Nephrol. 2010;21(12):2151-2156.

68. Imagawa S, Nakano Y, Obara N, et al. A GATAspecific inhibitor (K-7174) rescues anemia induced by IL-1beta, TNF-alpha, or L-NMMA. FASEB J. 2003;17(12):1742-1744.

69. Nakano Y, Imagawa S, Matsumoto K, et al. Oral administration of K-11706 inhibits GATA binding activity, enhances hypoxia-inducible factor 1 binding activity, and restores indicators in an in vivo mouse model of anemia of chronic disease. Blood. 2004;104(13):4300-4307.

70. Imagawa S, Matsumoto K, Horie M, et al. Does 
K-11706 enhance performance and why? Int J Sports Med. 2007;28(11):928-933.

71. Binley K, Askham Z, Iqball S, et al. Long-term reversal of chronic anemia using a hypoxiaregulated erythropoietin gene therapy. Blood. 2002;100(7):2406-2413.

72. Lasne F, Martin L, de Ceaurriz J, Larcher T, Moullier P, Chenuaud P. "Genetic doping" with erythropoietin cDNA in primate muscle is detectable. Mol Ther. 2004;10(3):409-410.

73. Gao G, Lebherz C, Weiner DJ, et al. Erythropoietin gene therapy leads to autoimmune anemia in macaques. Blood. 2004;103(9):3300-3302.

74. Chenuaud $P$, Larcher T, Rabinowitz JE, et al Autoimmune anemia in macaques following erythropoietin gene therapy. Blood. 2004;103(9): 3303-3304

75. Rivera VM, Gao GP, Grant RL, et al. Long-term pharmacologically regulated expression of erythropoietin in primates following AAV-mediated gene transfer. Blood. 2005;105(4):1424-1430.

76. Beiter T, Zimmermann M, Fragasso A, et al Establishing a novel single-copy primer-internal intron-spanning PCR (spiPCR) procedure for the direct detection of gene doping. Exerc Immunol Rev. 2008;14:73-85.

77. Beiter T, Zimmermann M, Fragasso A, et al Direct and long-term detection of gene doping in conventional blood samples. Gene Ther. 2011; 18(3):225-231.

78. Baoutina A, Coldham T, Bains GS, Emslie KR. Gene doping detection: evaluation of approach for direct detection of gene transfer using erythropoietin as a model system. Gene Ther. 2010; 17(8):1022-1032.

79. Lippin Y, Dranitzki-Elhalel M, Brill-Almon E, et al. Human erythropoietin gene therapy for patients with chronic renal failure. Blood. 2005;106(7): 2280-2286.

80. Sohmiya M, Ishikawa K, Kato Y. Stimulation of erythropoietin secretion by continuous subcutaneous infusion of recombinant human $\mathrm{GH}$ in anemic patients with chronic renal failure. Eur J Endocrinol. 1998;138(3):302-306.

81. Kurtz A, Jelkmann W, Bauer C. A new candidate for the regulation of erythropoiesis: insulin-like growth factor I. FEBS Lett. 1982;149(1):105-108.

82. Urena P, Bonnardeaux A, Eckardt KU, Kurtz A Drueke TB. Insulin-like growth factor I: a modulator of erythropoiesis in uraemic patients? Nephrol Dial Transplant. 1992;7(1):40-44.

83. Shahani S, Braga-Basaria M, Maggio M, Basaria S. Androgens and erythropoiesis: past and present. J Endocrinol Invest. 2009;32(8):704-716.

84. Johansson PI, Ullum H, Jensen K, Secher NH. A retrospective cohort study of blood hemoglobin levels in blood donors and competitive rowers. Scand J Med Sci Sports. 2009;19(1):92-95.

85. Beutler E, Waalen J. The definition of anemia: what is the lower limit of normal of the blood hemoglobin concentration? Blood. 2006;107(5): 1747-1750.

86. Gore CJ, Parisotto R, Ashenden MJ, et al Second-generation blood tests to detect erythropoietin abuse by athletes. Haematologica. 2003 88(3):333-344.

87. Malcovati L, Pascutto C, Cazzola M. Hematologic passport for athletes competing in endurance sports: a feasibility study. Haematologica. 2003; 88(5):570-581.

88. Robinson N, Sottas PE, Mangin P, Saugy M. Bayesian detection of abnormal hematological values to introduce a no-start rule for heterogeneous populations of athletes. Haematologica. 2007;92(8):1143-1144

89. Parisotto R, Gore CJ, Hahn AG, et al. Reticulocyte parameters as potential discriminators of recombinant human erythropoietin abuse in elite athletes. Int J Sports Med. 2000;21(7):471-479.

90. Parisotto R, Gore CJ, Emslie KR, et al. A nove method utilising markers of altered erythropoiesis for the detection of recombinant human erythropoietin abuse in athletes. Haematologica. 2000 85(6):564-572

91. Parisotto R, Wu M, Ashenden MJ, et al. Detection of recombinant human erythropoietin abuse in athletes utilizing markers of altered erythropoiesis. Haematologica. 2001;86(2):128-137.

92. Sharpe K, Hopkins W, Emslie KR, et al. Development of reference ranges in elite athletes for markers of altered erythropoiesis. Haematologica. 2002;87(12):1248-1257.

93. Sharpe K, Ashenden MJ, Schumacher YO. A third generation approach to detect erythropoietin abuse in athletes. Haematologica. 2006;91(3): 356-363.

94. Sottas PE, Robinson N, Saugy M, Niggli O A forensic approach to the interpretation of blood doping markers. Law Probability Risk. 2008;7(3): 191-210.

95. Sottas PE. Statistical classification of abnormal blood profiles in athletes. Int J Biostatistics. 2006; 2(1):Article 3

96. Segura J, Zorzoli M. Distinction between endogenous and exogenous erythropoietin: marker methods. In: Ghigo E, ed. Hormone Use and Abuse by Athletes. New York, NY: Springer; 2011 151-161.

97. Goodnough LT, Skikne B, Brugnara C. Erythropoietin, iron, and erythropoiesis. Blood. 2000; 96(3):823-833.

98. Damsgaard R, Munch T, Mørkeberg J, Mortensen SP, Gonzalez-Alonso J. Effects of blood withdrawal and reinfusion on biomarkers of erythropoiesis in humans: implications for antidoping strategies. Haematologica. 2006;91(7): 1006-1008.

99. Pottgiesser T, Specker W, Umhau M, Dickhuth HH, Roecker K, Schumacher YO. Recovery of hemoglobin mass after blood donation. Transfusion. 2008;48(7):1390-1397.

100. Pottgiesser T, Specker W, Umhau M, Roecker K, Schumacher YO. Post-transfusion stability of haemoglobin mass. Vox Sang. 2009;96(2):119127.

101. Pottgiesser T, Sottas PE, Echteler T, Robinson $N$ Umhau M, Schumacher YO. Detection of autologous blood doping with adaptively evaluated biomarkers of doping: a longitudinal blinded study [published online ahead of print March 7, 2011] Transfusion. doi: 10.1111/j.15372995.2011.03076.x

102. Mørkeberg J, Sharpe K, Belhage B, et al. Detecting autologous blood transfusions: a comparison of three passport approaches and four blood markers. Scand J Med Sci Sports. 2011;21(2): 235-243.

103. Mørkeberg J, Belhage B, Ashenden M, et al. Screening for autologous blood transfusions. Int J Sports Med. 2009;30(4):285-292.

104. Banfi G, Mauri C, Morelli B, Di Gaetano N, Malgeri U, Melegati G. Reticulocyte count, mean reticulocyte volume, immature reticulocyte fraction, and mean sphered cell volume in elite athletes: reference values and comparison with the general population. Clin Chem Lab Med. 2006; 44(5):616-622.

105. Parisotto R, Ashenden MJ, Gore CJ, Sharpe K Hopkins W, Hahn AG. The effect of common hematologic abnormalities on the ability of blood models to detect erythropoietin abuse by athletes. Haematologica. 2003;88(8):931-940.

106. Brugnara C, Colella GM, Cremins J, et al. Effects of subcutaneous recombinant human erythropoietin in normal subjects: development of decreased reticulocyte hemoglobin content and iron-deficient erythropoiesis. J Lab Clin Med. 1994;123(5):660-667.

107. Breymann C, Rohling R, Krafft A, Huch A, Huch R 'Blood doping' with recombinant erythropoietin (rhEPO) and assessment of functional iron defi- ciency in healthy volunteers. $\mathrm{Br} J \mathrm{Haematol}$ 2000;108(4):883-884.

108. Ashenden MJ, Fricker PA, Ryan RK, Morrison NK, Dobson GP, Hahn AG. The haematological response to an iron injection amongst female athletes. Int J Sports Med. 1998;19(7):474-478

109. Diaz V, Lombardi G, Ricci C, Jacobs RA, Lundby C, Banfi G. Reticulocyte and haemoglobin profiles in elite triathletes over four consecutive seasons. Int $J$ Lab Hematol. In press.

110. Banfi G, Del Fabbro M. Behaviour of reticulocyte counts and immature reticulocyte fraction during a competitive season in elite athletes of four different sports. Int J Lab Hematol. 2007;29(2):127131.

111. Major A, Bauer C, Breymann C, Huch A, Huch R. rh-erythropoietin stimulates immature reticulocyte release in man. Br J Haematol. 1994;87(3):605608.

112. Krzyzanski W, Perez-Ruixo JJ. An assessment of recombinant human erythropoietin effect on reticulocyte production rate and lifespan distribution in healthy subjects. Pharm Res. 2007;24(4):758772.

113. Russell G, Gore CJ, Ashenden MJ, Parisotto R, Hahn AG. Effects of prolonged low doses of recombinant human erythropoietin during submaximal and maximal exercise. Eur J Appl Physiol. 2002;86(5):442-449

114. Souillard A, Audran M, Bressolle F, Gareau R, Duvallet A, Chanal JL. Pharmacokinetics and pharmacodynamics of recombinant human erythropoietin in athletes. Blood sampling and doping control. Br J Clin Pharmacol. 1996;42(3):355364.

115. Casoni I, Ricci G, Ballarin E, et al. Hematological indices of erythropoietin administration in athletes. Int J Sports Med. 1993;14(6):307-311.

116. Breymann C, Bauer C, Major A, et al. Optimal timing of repeated rh-erythropoietin administration improves its effectiveness in stimulating erythropoiesis in healthy volunteers. Br J Haematol. 1996;92(2):295-301.

117. Ashenden MJ, Gore CJ, Parisotto R, Sharpe K, Hopkins WG, Hahn AG. Effect of altitude on second-generation blood tests to detect erythropoietin abuse by athletes. Haematologica. 2003; 88(9):1053-1062.

118. Abellan R, Ventura R, Remacha AF, Rodriguez FA, Pascual JA, Segura J. Intermittent hypoxia exposure in a hypobaric chamber and erythropoietin abuse interpretation. J Sports Sci. 2007;25(11): 1241-1250.

119. McLaren HR. CAS doping jurisprudence: what can we learn? Int Sports Law Rev. 2006; Issue 1:4-22.

120. Bornø A, Aachmann-Andersen NJ, MunchAndersen T, Hulston CJ, Lundby C. Screening for recombinant human erythropoietin using $[\mathrm{Hb}]$, reticulocytes, the OFF(hr score), OFF ( $z$ score) and $\mathrm{Hb}$ (z score): status of the Blood Passport. Eur J Appl Physiol. 2010;109(3):537-543.

121. Faber K, Sjerps M. Anti-doping researchers should conform to certain statistical standards from forensic science. Sci Justice. 2009;49(3): 214-215.

122. Sottas PE, Saudan C, Saugy M. Doping: a paradigm shift has taken place in testing. Nature. 2008;455(720):166.

123. Kayser B, Mauron A, Miah A. Current anti-doping policy: a critical appraisal. BMC Med Ethics. 2007;8:2.

124. Meinhardt U, Nelson AE, Hansen JL, et al. The effects of growth hormone on body composition and physical performance in recreational athletes: a randomized trial. Ann Intern Med. 2010; 152(9):568-577.

125. Jelkmann W. Erythropoiesis stimulating agents and techniques: a challenge for doping analysts. Curr Med Chem. 2009;16(10):1236-1247. 